\title{
TERSANGKA PENYALAHGUNA NARKOTIKA MENDAPATKAN BANTUAN HUKUM DALAM PROSES PENYIDIKAN
}

\author{
Agung Mustakim \\ PT. Agung Jaya Perkasa Engineering \\ E-mai: agung.mustakim76@gmail.com
}

\begin{tabular}{l|l|l} 
Masuk : Maret 2021 & Penerimaan : Juni 2021 & Publikasi : Juli 2021
\end{tabular}

\section{ABSTRAK}

Hak tersangka perkara penyalahgunaan Narkoba untuk mendapatkan bantuan hukum dalam proses penyidikan merupakan asas dan komponen penting dalam sistem peradilan pidana yang dapat melindungi hak asasi tersangka dalam pelaksanaan proses peradilan yang tidak memihak. Penelitian ini bertujuan untuk mengetahui, memahami dan mengkaji apakah bantuan hukum wajib diberikan kepada tersangka penyalahgunaan Narkoba dalam proses penyidikan sebagai perlindungan HAM, dan mengkaji bagaimanakah fungsi advokat menurut UUNo. 18 Tahun 2003 dihubungkan dengan kewajiban memberikan bantuan hukum kepada tersangka perkara penyalahgunaan Narkoba. Spesifikasi penelitian ini bersifat deskriptif analitis, guna memberikan gambaran tentang hak tersangka untuk mendapatkan bantuan hukum dalam proses penyidikan dan fungsi advokat serta kewajibannya memberikan bantuan hukum kepada tesangka penyalahgunaan Narkoba. Teknik analisis data yang digunakan adalah normatif kualitatif yaitu pemaparan dan penggambaran pengaturan penundang-undangan secara kualitatif yuridis. Berdasarkan hasil penelitian menunjukkan bahwa, bantuan hukum masih sekedar hak bukan kewajiban, padahal bantuan hukum bersifat imperatif dan sebagai perlindungan HAM karenanya bila bantuan hukum tidak diberikan adalah bertentangan dengan KUHAP, kemudian dengan tidak adanya sanksi atau lemahnya aturan hukum karena kepada penegak hukum yang lalai dan menghindar untuk tidak memberikan hak tersangka untuk mendapatkan bantuan hukum padahal ancaman hukuman diatas lima tahun dengan adanya surat pernyataan tersangka yang dibuat penyidik.

Kata Kunci : Advokat; Bantuan; Hukum; Narkotika.

\begin{abstract}
The right of suspects in drug abuse cases to obtain legal assistance in the investigation process is an important principle and component of the criminal justice system that can protect the suspect's human rights in the implementation of an impartial judicial process. This study aims to find out, understand and examine whether legal aid must be given to suspects of drug abuse in the investigation process as a protection of human rights, and to examine how the function of advocates according to Law no. 18 of 2003 is related to the obligation to provide legal assistance to suspects in drug abuse cases. The specifications of this research are descriptive and analytical, in order to provide an overview of the rights of suspects to obtain legal assistance in the investigation process and the function of advocates and their obligations to provide legal assistance to suspected drug abusers. The data analysis technique used is normative qualitative, namely the presentation and description of legal arrangements in a qualitative juridical manner. According to the study's findings, legal aid is still just a right, not an obligation, even though it is an imperative and a protection of human rights; if legal aid is not
\end{abstract}


provided, it is contrary to the Criminal Procedure Code, in the absence of sanctions or weak legal rules due to negligent law enforcers, and avoiding giving the suspect the right to obtain legal assistance; if legal aid is not provided, it is contrary to the Criminal Procedure Code, in the absence of sanctions or weak legal rules due to negligent law enforce.

Keywords : Advocate; Help; Law; Narcotics.

\section{A. PENDAHULUAN}

Penyalahgunaan Narkotika, psikotropika dan zat adiktif lainnya (selanjutnya akan disebut narkoba) merupakan permasalahan kompleks baik dilihat dari faktor penyebab maupun akibatnya. Penyebabnya merupakan kompleksitas dari berbagai faktor, termasuk faktor fisik dan kejiwaan pelaku, serta faktor lingkungan baik mikro maupun makro. Akibatnya juga sangat kompleks dan luas tidak hanya terhadap pelakunya, tetapi juga menimbulkan beban psikologis, sosial dan ekonomis, bagi orang tua dan keluarganya, serta menimbulkan dampak yang merugikan terhadap berbagai aspek kehidupan masyarakat, bangsa dan umat manusia (BNN, 2004).

Banyak orang memandang masalah narkoba sebagai "aib" keluarga sehingga harus disembunyikan atau ditutup-tutupi, padahal sesungguhnya masalah penyalahgunaan narkoba merupakan masalah sosial yang mempengaruhi banyak orang dan mempunyai risiko yang sangat luas, dan orang-orang yang terlibat masalah narkoba adalah orang-orang yang mempunyai nilai-nilai kepribadian yang menyimpang dan mereka itu berhak untuk diperlakukan sebagai orang yang membutuhkan pertolongan dan perawatan.

Proses peradilan pidana bagi tersangka dalam perkara penyalahgunaan Narkoba, yang dimulai dari penyelidikan, penyidikan, penangkapan, penahanan, penuntutan, pemeriksaan di persidangan, hingga pemidanaan, merupakan kegiatan yang sangat kompleks dan dapat dikatakan tidak mudah dipahami serta kadangkala menakutkan bagi masyarakat awam (Sahetapy, 1982).

Bantuan Hukum dalam pengertian yang luas diartikan sebagai upaya untuk membantu golongan yang tidak mampu dalam bidang hukum, sedangkan dalam KUHAP tidak merumuskan tentang arti bantuan hukum. Padahal harus 
diakui bahwa sebagian besar pelaku tindak pidana adalah mereka dari golongan yang tidak mampu dan buta hukum, dan bagi pelaku penyalahgunaan Narkoba yang merupakan orang yang sedang kecanduan, baik secara fisik maupun psikis, sehingga bantuan hukum merupakan hal yang mutlak diperlukan bila ingin dicapai peradilan yang layak dan jujur (fair trial) (Reksodiputro, 1997).

Menurut 54 KUHAP guna kepentingan pembelaan, tersangka atau terdakwa berhak mendapat bantuan hukum dari seorang atau lebih penasihat hukum selama dalam waktu dan pada setiap tingkat pemeriksaan, menurut tata cara yang ditentukan dalam undang-undang. Sementara itu menurut Pasal 1 Undang-Undang Nomor 18 tahun 2003 advokat adalah orang yang berprofesi memberi jasa hukum, baik di dalam maupun di luar pengadilan yang memenuhi persyaratan berdasarkan ketentuan Undang-Undang. menurut ketentuan tersebut tersangka sebenarnya dapat dikatakan sangat limitatif, karena di Indonesia dalam proses penyidikan suatu perkara penyalahgunaan Narkoba, seseorang sebelum ditentukan, disahkan statusnya sebagai tersangka penylalahguna tersebut sudah menjalani tahap-tahap pemeriksaan awal, misalnya pemeriksaan Laboratorium dan barang bukti yang diduga Narkoba.Keberadaan penasehat hukum sangat diperlukan dalam sistem peradilan pidana yang menerapkan asas praduga tak bersalah. Terdapat beberapa masalah yang penulis identifikasi yang menjadi bahasan yaitu tentang :

1. Bantuan Hukum wajib diberikan kepada tersangka penyalahgunaan Narkoba dalam proses penyidikan sebagai perlindungan HAM.

2. Fungsi advokat menurut Undang-Undang Nomor 18 Tahun 2003 dihubungkan dengan kewajiban memberikan bantuan hukum kepada tersangka penyalahgunaan Narkoba

\section{B. METODE PENELITIAN}

Penelitian ini merupakan penelitian bersifat Deskriptif Analitis. Desktiftif analisis yaitu melukiskan fakta-fakta berupa data dengan bahan antara lain data primer, data skunder dan data tersier. Teknis analisis data yang digunakan dalam penelitian ini adalah normatif kualitatif, yaitu pemaparan dan penggambaran 
peraturan perundang-undangan secara kualitatif yuridis (perundang-undangan yang satu dengan yang lain tidak boleh bertentangan, hirarkis perundangundangan, dan kepastian hukum/meneliti apakah peraturan perundang-undangan yang ada adalah kebijakan hukum yang tepat bagi penanggulangan kejahatan.

\section{PEMBAHASAN}

Bantuan hukum sebenarnya sudah dikenal sejak jaman Romawi, di mana pada waktu itu bantuan hukum berada dalam bidang moral dan lebih dianggap sebagai suatu pekerjaan yang mulia dan khususnya untuk menolong orang tanpa mengharapkan dan atau menerima imbalan atau honorium (Bambang Sunggono, 2001).

Tahun 1981 lahir Undang-undang Nomor 8 Tahun 1981 Tentang Hukum Acara Pidana. Di dalam Bab VII nya mengatur tentang hak untuk mendapatkan bantuan hukum kepada tersangka dan terdakwa sebagaimana dimuat dalam Pasal 54 dan Pasal 114 Undang-undang Nomor 8 Tahun 1981 tentang KUHAP Guna kepentingan pembelaan tersangka atau terdakwa berhak untuk mendapat bantuan hukum dari seseorang atau lebih penasehat hukum selama dalam waktu dan pada setiap tingkat pemeriksaan, menurut tata cara yang ditentukan dalam undangundang ini.

Pasal 114 KUHAP menerangkan bahwa apabila seseorang disangka melakukan suatu tindak pidana sebelum dimulai pemeriksaan oleh penyidik wajib memberitahukan kepadanya tentang haknya untuk mendapatkan bantuan hukum atau bahwa ia dalam perkaranya itu wajib didampingi oleh Penasehat Hukum sebagaimana dimaksud dalam Pasal 56".

Menurut Mardjono Reksodiputro, hak-hak yang diberikan KUHAP tersebut di atas bukan kepada tersangka dan terdakwa sebagai pelanggar hukum, tetapi sebagai "manusia" yang mempunyai hak dan kewajiban, manusia sebagai objek dan subjek anggota masyarakat (Reksodiputro, 2003).

Pasal 55 KUHAP juga dapat menafsirkan diskriminasi terhadap tersangka dan memungkinkan bagi orang mampu untuk lebih mudah mendapatkan bantuan hukum, sebagaimana dinyatakan bahwau ntuk mendapatkan penasihat hukum 
tersebut dalam Pasal 54, tersangka atau terdakwa berhak memilih sendiri penasihat hukumnya

Jadi kebebasan dan hak untuk memilih penasihat hukum yang dikehendaki oleh tersangka atau terdakwa yang ditentukan oleh Pasal 55 KUHAP, lebih mirip memberi keuntungan kepada orang kaya, tetapi kepada orang yang tak punya, ketentuan itu hanya slogan yang terlampau jauh untuk dijangkaunya.

Pendapat yang sama juga dikatakan Komariah Emong Sapardjaja, bahwa tetaplah terdakwa yang dirugikan, hal ini selalu dapat terjadi karena jaminan hakhak terdakwa dalam hukum pidana dan hukum acara pidana di Indonesia belum cukup memadai yang semestinya jaminan Hak Asasi Manusia harus tercermin dalam hukum acara pidananya (Sapardjaja, 2002).

KUHAP juga memberikan batasan yang tegas dengan memakai istilah wajib yang merupakan perintah langsung dari undang-undang untuk mendapatkan bantuan hukum bagi tersangka dan terdakwa yang diatur dalam Pasal 56 yang berbunyi:

1. Dalam hal tersangka atau terdakwa disangka atau didakwa melakukan tindak pidana yang diancam dengan pidana mati atau ancaman pidana lima belas tahun atau lebih bagi mereka yang tidak mampu yang diancam dengan pidana lima tahun atau lebih yang tidak mempunyai penasihat hukum sendiri, pejabat yang bersangkutan pada semua tingkat pemeriksaan dalam proses peradilan wajib

2. Setiap penasihat hukum yang ditunjuk untuk bertindak sebagaimana dimaksud dalam ayat (1), memberikan bantuannya secara cuma-cuma".

Hakikat suatu hak, sebagaimana adagium ubi jus ibi remedium yang maknanya di mana ada hak, di sana ada kemungkinan menuntut, memperoleh atau memperbaiki apabila dilanggar. Menurut Mardjono Reksodiputro kelanjutan adagium ini adalah bahwa hanya ada kemungkinan (melalui proses hukum) untuk menuntutnya dapatlah dikatakan adanya suatu hak itu. Suatu hak yang tidak mempunyai kemungkinan untuk dipertahankan, dalam arti memintanya dilindungi (diperbaiki) apabila dilanggar, bukanlah suatu hak yang efektif” (Reksodiputro, 1998). 
Konvensi anti penyiksaan Pasal 15 (CAT) yang menyatakan: "segala pernyataan yang diperoleh sebagai akibat kekerasan dan penyiksaan tidak boleh diajukan sebagai bukti dalam proses apapun”. Indonesia telah meratifikasi konvensi ini yang seharusnya mengikat dan tunduk pada aturan konvensi ini. Sehingga suatu berita acara penyidikan yang akan berakibat dimungkinkan pembatalan (Loqman, 1990).

Semenjak adanya Undang-undang No. 18 Tahun 2003 tentang Advokat, ada kewajiban bagi advokat untuk memberikan bantuan hukum secara cuma-cuma. Dalam Pasal 22 ayat (1) disebutkan “Advokat wajib” memberikan bantuan hukum secara cuma-cuma kepada pencari keadilan yang tidak mampu." Pemberian bantuan hukum cuma-cuma menjadi bagian idealisme advokat, seharusnya setiap advokat harus mau menjalankan profesi mulia (officium nobile) dengan memberikan bantuan hukum cuma-cuma yang merupakan amanat dari Undangundang No. 18 Tahun 2003 Tentang Advokat.

Semenetara itu dalam konteks sistem peradilan pidana dan bantuan hukum, Bantuan hukum merupakan penjabaran dari hak untuk diakui secara pribadi di hadapan hukum dan subjek hukum, yang diklasifikasikan sebagai Hak Nonderogable Right. Indonesia sebagai suatu negara hukum, telah membuat pengaturan yang jelas dalam UUD 1945, di mana Hak Asasi Manusia mutlak diperlukan. Sebagai negara hukum diartikan bahwa Indonesia menyandarkan segala persoalannya melalui jalur hukum

Dalam konteks perlindungan harkat dan martabat manusia khususnya tentang pemenuhan dan perlindungan HAM, penegakkan hukum tidak dapat dilepaskan dari proses peradilan pidana itu sendiri sebagai "desain prosedur" dalam sistem peradilan pidana. Tujuan hukum acara pidana melaksanakan proses hukum yang adil (due process of law). Due process of law menurut Mardjono Reksodiputro diartikan sebagai "proses hukum yang adil" yang arti, makna dan hakekatnya adalah adanya hak atas kemerdekaan dari seseorang warga negara untuk membela diri dan menuntut hak-haknya dengan pengakuan atas kebersamaan kedudukan dalam hukum dan penghormatan kepada asas praduga tak bersalah". 
Sistem hukum yang baik, berusaha untuk membatasi tindakan yang merugikan masyarakat demi rasa aman masyarakat itu sendiri. Manakala masyarakat merasa tidak aman, terjadilah tindakan-tindakan, masyarakat main hakim sendiri atau "take the law into their own hands'. Tindakan main hakim sendiri adalah perwujudan gagalnya pemerintahan dalam memberikan perlindungan dan jaminan rasa aman kepada masyarakat, baik terhadap keamanan jiwa maupun harta bendanya. Kondisi ini diakibatkan oleh (Ebbe, 2013):

1. Pengabaian Hukum (disregarding the laws);

2. Ketidakhormatan pada hukum (disrespecting the law);

3. Ketidakpercayaan pada hukum (distrusting the law); serta

4. Penyalahgunaan hukum (misuse of the law).

Oleh karena itu, untuk mencegah tindakan main hakim sendiri oleh masyarakat, tugas menciptakan keamanan masyarakat itu diserahkan kepada negara melalui Sistem Peradilan Pidana. Perkembangan Sistem Peradilan Pidana dapat dilihat dari bentuk-bentuk hukuman, tambahan jenis hak untuk pelaku dan korban, dan reformasi penegakan hukum sejak zaman kuno. Perkembangan ini dapat dilihat dari berubahnya kebiasaan, ide politik dan kondisi ekonomi.

"Dalam peradilan pidana terdakwa mempunyai pertimbangan yang subyektif dalam posisi yang subyektif; penasihat hukum mempunyai pertimbangan yang objektif dalam posisi yang subyektif; penuntut umum mempunyai pertimbangan yang subyektif dalam posisi yang objektif, sedangkan hakim mempunyai pertimbangan yang objektif pula."

Hukum Pidana yang dikodifikasi dalam KUHP digolongkan sebagai Hukum Pidana materiel, sedangkan Hukum Acara Pidana (Strafprocesrecht) digolongkan sebagai Hukum Pidana formal. Sampai sekarang tidak ada kesamaan pendapat tentang arti dari Hukum Acara Pidana, tetapi dari penempatannya dalam sistematika ilmu hukum, setidak-tidaknya fungsi dari hukum Acara Pidana tersebut dapat diketahui (C. Samosir, 1985).

S.M. Amir mendefinisikan hukum acara sebagai kumpulan ketentuanketentuan dengan tujuan memberikan pedoman dalam usaha mencari kebenaran dan keadilan bila terjadi perkosaan atas suatu ketentuan hukum dalam hukum 
materiil. Dalam kata lain, hukum acara mengabdi kepada hukum materiil (Amir, 1976).

Sementara, Wirjono Prodjodikoro menyebutkan bahwa Hukum Acara Pidana berhubungan erat dengan Hukum Pidana. Hukum Acara Pidana merupakan suatu rangkaian peraturan-peraturan yang memuat cara bagaimana badan-badan pemerintah yang berkuasa, yaitu kepolisian, kejaksaan dan pengadilan harus bertindak guna mencapai tujuan negara dengan mengadakan Hukum Pidana.

Apabila kedua pendapat di atas berupaya menjelaskan kedudukan Hukum Pidana formal terhadap Hukum Pidana material, Fletcher berupaya menunjukkan bagaimana perbedaan cara pandang antara Hukum Pidana materiil dengan Hukum Pidana formal. Jika seseorang melakukan delik dan atas delik tersebut ia telah diberi sanksi, dari sudut pandang Hukum Pidana Materiil, setelah masa hukuman berakhir, terpidana tidak lagi bersalah. Untuk kasus yang sama dari sudut pandang Hukum Pidana formal, setelah masa hukuman berakhir, kesalahan itu sendiri tetap ada tetapi terpidana tidak dapat dihukum (Fletcher, 1998).

Sementara itu menurut konsepsi Hak Asasi Manusia dalam Perspektif Hukum Nasional Bagir Manan menjelaskan bahwa yang dimaksud dengan HAM adalah (Manan, 1998):

1. Hak-hak asasi baik yang bersifat klasik maupun yang bersifat sosial. Hakhak yang bersifat klasik terdapat dalam Pasal 27 ayat (1), Pasal 28, Pasal 29 ayat (2) UUD 1945. Sementara hak yang bersifat sosial dirumuskan dalam Pasal 27 ayat (2), Pasal 31 ayat (1) dan Pasal 24 UUD 1945. Hak yang berkenaan dengan semua orang yang berkedudukan sebagai penduduk tidak dirumuskan dengan hak melainkan kemerdekaan. Contohnya rumusan Pasal 28 dan 29 ayat (2) UUD 1945.

2. Hak yang berkenaan dengan warga negara Indonesia, Hal ini dapat kita baca pada Pasal 27 ayat (2), Pasal 30 ayat (1) dan Pasal 31 ayat (1). Hak asasi yang berlaku khusus pada warga negara ini dapat dikategorikan ke dalam hak asasi yang timbul karena hukum (legal rights) (Kaligis, 2006). 
Ketentuan pasal-pasal dalam UUD 1945 sebagaimana dimaksud di atas, secara normatif konstitusional memberikan jaminan kepada setiap orang: Pertama, kedudukan dan perlakuan yang sama di hadapan hukum, kedua, perlindungan dan kepastian hukum yang adil; ketiga, perlindungan diri pribadi, keluarga, kehormatan, martabat dan harta benda yang di bawah kekuasaannya; keempat, rasa aman dan perlindungan dari ancaman ketakutan untuk berbuat atau tidak berbuat sesuatu yang merupakan hak asasinya; kelima, untuk bebas dari penyiksaan atau perlakuan yang merendahkan derajat martabat manusia; keenam; hak untuk hidup, hak kemerdekaan pikiran dan hati nurani, hak beragama, hak untuk tidak diperbudak, hak untuk diakui sebagai pribadi di hadapan hukum, hak untuk tidak dituntut atas dasar hukum yang berlaku surut; ketujuh, mendapatkan perlindungan dan bebas dari perlakuan yang bersifat diskriminatif atas dasar apapun. Kesemuanya ini bermuara pada prinsip persamaan kedudukan di hadapan hukum (equality before the law).

Di samping asas persamaan kedudukan di hadapan hukum (equality before the law) menjadi elemen pokok dari konsepsi HAM, juga dikenal elemen lainnya, yaitu asas peradilan yang berimbang (fair trial). Pengaturan kedua asas ini dalam peraturan perundang-undangan dan implementasinya dalam penegakkan hukum menjadi tolok ukur sejauh mana HAM dijamin dan ditegakkan dan kedua asas ini saling mempengaruhi. Persamaan kedudukan di hadapan hukum (equality before the law) dapat terwujud bila ada peradilan yang berimbang (fair trial). Sebaliknya, peradilan yang berimbang (fair trial) dapat terjadi bila persamaan kedudukan di hadapan hukum (equality before the law) dikedepankan dalam proses peradilan.

Pertanyaan mengenai peradilan yang berimbang (fair trial) dan nilai fundamental apa yang menjadi inti dari peradilan yang berimbang (fair trial), secara sederhana dapat dijelaskan sebagai berikut : peradilan yang berimbang (fair trial) adalah seluruh tahapan proses peradilan dalam rangka penegakkan HAM, termasuk hak asasi tersangka, terpidana dan terdakwa, harus dijalankan berdasarkan etika (moral), akal sehat (rasional) dan hati nurani yang bersih, 
dengan berpegang teguh kepada integritas (moral/imparsial) yang dapat dibenarkan secara filosofis, teoretis, normatif dan sosiologis.

Berkenaan dengan integritas ini, Stephen L. Carter mengatakan bahwa integritas membutuhkan 3 (tiga) langkah :

1. Membedakan apa yang benar dengan apa yang salah;

2. Melaksanakan apa yang telah dikaji itu, bahkan bila menderita rugi;

3. Mengatakan secara terbuka bahwa anda sedang melaksanakan berdasarkan pemahaman anda mengenai apa yang benar dan yang salah.

Kriteria yang pertama menuntut suatu derajat perenungan moral untuk dapat mencapai integritas. Tahap yang kedua menuntut keteguhan seseorang dalam memenuhi janji-janjinya. Tahap yang ketiga mengingatkan kita bahwa seseorang yang memiliki integritas itu tidak malu-malu melakukan hal yang benar. Mencermati pengertian peradilan yang berimbang (fair trial) tersebut, dapat dikatakan bahwa nilai fundamental yang menjadi inti dari peradilan yang berimbang (fair trial) adalah etika (ethics) atau moral.

Dengan demikian, dapat dikatakan bahwa peradilan yang berimbang (fair trial) yang tetap mengedepankan persamaan kedudukan di hadapan hukum (equality before the law) menjadi prasyarat mutlak dalam rangka melindungi hak asasi tersangka, terdakwa dan terpidana. Bila tidak demikian, penegakan HAM pada umumnya dan khususnya dalam penegakan hak asasi tersangka, terdakwa dan terpidana hanya suatu angan-angan belaka.

Berikutnya dalam proses penyidikan tindak pidana narkotika. Penyidikan tindak pidana Narkotika diatur dalam Pasal 65 sampai Pasal 74 Undang-Undang Nomor 22 Tahun1997 sebagaimana diubah menjadi Undang-Undang Nomor 35 Tahun 2009 dan penyidikan tindak pidana Psikotropika diatur dalam Pasal 55, 56, 57 dan 58 Undang-Undang Nomor.5 Tahun.1997.

Pengertian penyidik adalah Pejabat Polisi Negara Republik Indonesia atau Pejabat Pegawai Negeri Sipil tertentu yang diberi wewenang khusus oleh undangundang untuk melakukan penyidikan (Pasal 1 angka 1 dan Pasal 6 ayat (1) huruf a dan b KUHAP). 
Dalam Pasal 65 Undang-Undang Nomor 22 Tahun. 1997 sebagaimana di ubah menjadi Undang-Undang Nomor 35 Tahun 2009, penyidik juga terdiri dari:

1. Penyidik Polisi Negara Republik Indonesia (penyidik POLRI);

2. Penyidik Pegawai Negeri Sipil (Penyidik PNS).

Di dalam penjelasan Pasal 56 disebutkan Penyidik PNS dalam UndangUndang Nomor 5 Tahun. 1997 meliputi :

1. Penyidik PNS Kementeriaan yang bertanggung jawab di bidang kesehatan;

2. Penyidikan PNS kementeriaan Keuangan, dalam hal ini Direktorat Jenderal Bea dan Cukai;

3. Penyidik PNS kementerian terkait lainnya.

Kewenangan PPNS departemen tersebut diberikan oleh Undang-Undang Nomor 5 Tahun 1997 ini pada bidang tugasnya masing-masing.Hubungan penyidik POLRI dengan penyidik PNS. Di dalam KUHAP mengatur tentang Penyidik POLRI dan Penyidik PNS, serta, mengatur bagaimana hubungan kerja keduanya. Hubungan keduanya:

1. Penyidik PNS dalam pelaksanaan tugasnya di bawah koordinasi dan pengawasan penyidik POLRI (Pasal 7 ayat (2) KUHAP);

2. Untuk kepentingan penyidikan, penyidik POLRI memberikan petunjuk kepada penyidik PNS dan memberikan bantuan penyidikan yang diperlukan (Pasal 107 ayat (1) KUHAP);

3. Penyidik PNS melaporkan adanya tindak pidana yang sedang disidik kepada Penyidik POLRI (Pasal 107 ayat (2) KUHAP);

4. Penyidik PNS menyerahkan hasil penyidikan yang telah selesai kepada penuntut umum melalui Penyidik POLRI (Pasal 107 ayat (3) KUHAP);

5. Dalam hal Penyidik PNS menghentikan penyidikan; segera memberitahukan kepada Penyidik POLRI dan Penuntut Umum (Pasal 109 ayat (3) KUHAP).

Mengingat masalah narkotika sangat berbahaya bagi individu, masyarakat dan negara maka wewenang Penyidik POLRI diperluas. Perluasan wewenang tersebut sangat diperlukan sekali untuk menguak terjadinya tindak pidana di bidang Narkotika. Wewenang tersebut bisa dikatakan sangat istimewa dan tidak terdapat dalam peraturan perundang-undangan yang lain. 
Kewenangan penyidik PNS dalam KUHAP disebutkan sesuai dengan undang-undang yang menjadi dasar hukumnya masing-masing (Pasal 7 ayat (2) KUHAP). Kewenangan tersebut juga diperluas sebagaimana diatur dalam Pasal 65 ayat (2) UU No. 22/Th.1997, yaitu:

1. melakukan pemeriksaan atas kebenaran laporan serta keterangan tentang tindak pidana narkotika;

2. melakukan pemeriksaan terhadap orang yang diduga melakukan tindak pidana narkotika;

3. meminta keterangan dan barang bukti dari orang dan badan hukum sehubungan dengan tindak pidana di bidang narkotika;

4. melakukan pemeriksaan atau penyitaan bahan atau barang bukti dalam perkara tindak pidana narkotika;

5. melakukan pemeriksaan surat/atau dokumen lain tentang tindak pidana narkotika;

6. meminta bantuan tenaga ahli dalam rangka pelaksanaan tugas penyidikan tindak pidana narkotika.

Khusus kewenangan Penyidik PNS kementerian Kesehatan dalam tindak pidana kesehatan sebelumnya sudah diatur dalam Undang-Undang Nomor 36 Tahun 2009 tentang kesehatan, dalam Pasal 79 ayat (2), yaitu:

1. melakukan pemeriksaan atas kebenaran laporan serta keterangan tentang tindak pidana;

2. melakukan pemeriksaan orang yang diduga melakukan tindak pidana;

3. meminta keterangan dan barang bukti dari orang dan badan hukum;

4. melakukan pemeriksaan atas surat dan atau dokumen lain;

5. melakukan pemeriksaan atau penyitaan bahan atau barang bukti dalam perkara;

6. meminta bantuan ahli dalam rangka pelaksanaan tugas penyidikan tindak pidana;

7. menghentikan penyidikan apabila tidak terdapat cukup bukti yang membuktikan tentang adanya tindak pidana. 
Terhadap ke dua ketentuan tersebut, kewenangan Penyidik PNS kementerian Kesehatan mirip dengan yang diatur dalam Undang-Undang Nomor. 5 Tahun.1997 yaitu sebagai berikut. dalam melakukan penyidikan, penyidik perlu menyadari bahwa tindak pidana narkotika merupakan perkara yang diprioritaskan untuk pemeriksaan dan penyelesaiannya. Untuk itu harus secepatnya untuk diajukan ke pengadilan. Wewenang penyidik secara umum adalah sebagai berikut:

a. Berwenang membuka dan memeriksa setiap barang kiriman melalui pos atau berhubungan lainnya yang diduga keras ada hubungannya dengan tindak pidana narkotika (Pasal 66 ayat (1));

b. Dapat melakukan penangkapan terhadap seseorang yang diduga berdasarkan alat bukti yang cukup melakukan tindak pidana narkotika paling lama 24 jam (Pasal 67 ayat (1)) dan dapat diperpanjang 48 jam atas ijin atasan langsung (Pasal 67 ayat (2));

c. Melakukan penyitaan (Pasal 69).

Menurut bentuknya, pelanggaran-pelanggaran terhadap hak asasi tersangka dapat dikategorikan dalam 3 (bagian), yaitu :

1. Pelanggaran administratif dan prosedural penyelidikan dan penyidikan;

2. Pelanggaran terhadap diri pribadi (jiwa/raga dan harta) tersangka;

3. Pelanggaran HAM yang tidak diatur dalam KUHAP.

Sekalipun bentuk-bentuk pelanggaran hak asasi tersangka dapat ditinjau dalam berbagai bentuk sebagaimana disebut di atas, tetapi tidak tertutup kemungkinan bahwa dalam suatu perkara Narkoba terjadi beberapa bentuk pelanggaran, baik pelanggaran administratif, pelanggaran prosedural, maupun pelanggaran terhadap diri pribadi tersangka penyalahgunaan Narkotika

Pada praktiknya, tersangka berhadapan dengan penyidik yang memiliki hak diskresi sangat besar dan sangat cenderung tidak terkendali, seperti: penggunaan kekerasan yang eksesif (police brutality), penyalahgunaan kekuasaan, dan korupsi. Diskresi yang tidak terkendali selalu menyebabkan pelanggaran HAM. Oleh karena itu, hak atas bantuan hukum seharusnya wajib diberikan dalam setiap penyidikan terhadap tersangka penyalahgunaan Narkotika. Terlebih karena Penyalahguna Narkoba adalah perbuatan seseorang yang menggunakan 
Narkotika, tanpa pengawasan dokter, dan yang dimaksud dengan pengguna adalah juga meliputi pecandu yang secara medis adalah orang-orang yang mempunyai nilai-nilai kepribadian yang menyimpang dan mereka itu berhak untuk diperlakukan sebagai orang yang membutuhkan pertolongan dan perawatan serta harus selalu berada dalam pengawasan dokter.

KUHAP telah menempatkan tersangka dalam posisi his entity and dignity as a human being, yang harus diperlakukan sesuai dengan nilai-nilai luhur kemanusiaan. Dalam pelaksanaan penegakkan hukum, hak-hak asasi yang melekat pada diri tersangka tidak boleh dikurangi. Berdasarkan KUHAP, hak-hak asasi utama tersangka yang harus dijunjung antara lain: Persamaan hak dan kedudukan serta kewajiban di hadapan hukum dan Praduga tak Bersalah

Suatu proses peradilan pidana sesungguhnya juga merupakan perjuangan "kemanusiaan yang adil dan beradab" (atau sering disebut juga hak-hak asasi manusia). "Oleh karena itu pulalah berbicara proses peradilan pidana dan bantuan hukum tidak bisa dilepaskan dari pembicaraan tentang hak asasi. Peradilan pidana dan bantuan hukum adalah salah satu aspek dari perjuangan hak asasi manusia.

Bantuan hukum dan peradilan pidana adalah satu nafas dalam praktik penegakkan hukum, atau juga dapat dikatakan dua sisi mata uang yang sama. Artinya bantuan hukum dalam suatu proses peradilan pidana tidak dapat dilepaskan dihindarkan apalagi ditiadakan sama sekali.

Menurut Willi Soenarto. kewajiban tersebut melekat untuk menyediakan penasehat hukum bagi tersangka atau terdakwa yang diancam pidana sebagaimana dalam pasal 56 ayat (1) KUHAP dan seandainya ada penolakan maka akan tetap disediakan dan ditugaskan untuk mendampingi pada saat dilakukan pemeriksaan. Begitu pula pendapat Frans Tri Harsono Adi, "Penolakan tersebut tidak menghilangkan kewajiban dari pejabat guna pemenuhan kewajiban baik secara maksimal sekalipun ada penolakan dari tersangka dan atau terdakwa, sekalipun di tempat itu tidak ada penasehat hukum, maka penunjukan dapat dilakukan kepada orang lain yang cakap untuk tugas itu (Wahid, 1994). 
Semetara itu fungsi Advokat menurut Undang-Undang No. 18 Tahun 2003 Tentang Advokat Dihubungkan dengan kewajiban Memberikan Bantuan Hukum adalah dengan bebas dan berani tetapi penuh tanggung jawab memberikan bantuan hukum dan nasehat hukum, baik diluar maupun di muka pengadilan, kepada setiap orang yang memerlukannya karena terancam jiwanya, kebebasannya, hak miliknya dan nama baiknya, dengan mencurahkan segenap keahliannya yang didasarkan kepada ilmu pengetahuan, sehingga dengan demikian advokat turut membantu menegakkan hukum, keadilan dan kebenaran.

Advokat harus mampu bertindak sebagai agent of law development dan agen of law enculturation. Hal ini dimaksudkan untuk mencari kebenaran dan menegakkan keadilan serta menjunjung tinggi supremasi hukum untuk menjamin terselenggaranya negara hukum dalam Negara Kesatuan Republik Indonesia. Pada mulanya advokat merupakan wujud moral force, kekuatan moral yang dilakukan oleh sekelompok orang, sejalan dengan perkembangan kehidupan dan kesadaran masyarakat di berbagai bidang, khususnya di bidang hukum. Jasa hukum melalui advokat dewasa ini berkembang menjadi kekuatan Institusional.

Dalam masalah kedudukan penasihat hukum pada pemeriksaan penyidikan terhadap tersangka penyalahgunaan Narkoba oleh sementara golongan dianggap bersifat reaktif dan merupakan cacat cela yang menodai kehadiran KUHAP. Oleh karena itu penulis dapat menilai ketentuan Pasal 115 sebagai salah satu cacat, karena belum memberikan dan meletakkan landasan persamaan derajat dan kedudukan antara penyidik dengan penasehat hukum Penulis beranggapan, undang-undang belum memberi tempat yang wajar bagi lembaga bantuan hukum.

Penasehat hukum masih dicurigai sebagai orang-orang yang mengganggu kelancaran pemeriksaan, ketentuan Pasal 115 masih bersifat fakultatif. Belum dapat dikatakan sebagai hak penasehat hukum untuk mendampingi tersangka di dalam pemeriksaan penyidikan. Sekurang-kurangnya ketentuan Pasal 115 belum memberi "bagi penasehat hukum, hak yang utuh" dan menganulir pasal-pasal sebelumnya.

Supaya ketentuan Pasal 115 KUHAP benar-benar proporsional dengan landasan filosofis dan konstitusional yang mengakui dan mengagungkan harkat 
martabat manusia sebagai makhluk Tuhan yang harus diperlakukan berdasar perikemanusiaan yang adil dan beradab, maupun dari landasan rule of law atau legalitas yang mempersamakan manusia di hadapan hukum (equality before the law) dan atas praduga tak bersalah (presumption of innocent), perkataan "dapat" pada Pasal 115 harus ditafsirkan sebagai "hak" bagi penasehat hukum dan "kewajiban" bagi pejabat penyidik, dengan penggarisan bahwa hak itu hanya boleh dibatasi penyidik dalam hal-hal yang "sangat terbatas".

Terlepas bagaimana perjalanan Pasal 115 dalam praktek penegakkan hukum, secara harfiah dapat kita uraikan:

1. Pada waktu pejabat penyidik melakukan pemeriksaan terhadap tersangka penyalahgunaan Narkoba, penyidik "dapat" memperbolehkan atau mengijinkan penasehat hukum untuk mengikuti jalannya pemeriksaan

2. Kedudukan dan kehadiran penasehat hukum mengikuti jalannya pemeriksaan penyidikan terhadap tersangka perkara penyalahgunaan Narkotika adalah "secara pasif".

\section{PENUTUP}

\section{Kesimpulan}

Bantuan Hukum wajib diberikan dalam rangka perlindungan HAM kepada tersangka dalam perkara penyalahgunaan Narkoba karena merupakan perintah langsung dari undang-undang yang bersifat secara imperatif. Dan pemerintah wajib menjamin tersedianya bantuan hukum dalam bentuk penyediaan sistem yang memastikan bantuan hukum dapat bekerja efektif memberikan fasilitas maupun dukungan dana. Kemudian proses peradilan pidana dan bantuan hukum tidak bisa dilepaskan dari pembicaraan tentang hak asasi. Peradilan pidana dan bantuan hukum adalah salah satu aspek dari perjuangan hak asasi manusia. Oleh karena itu KUHAP telah menempatkan tersangka dalam posisi his entity and dignity as a human being, yang harus diperlakukan sesuai dengan nilai-nilai luhur kemanusiaan. Dalam pelaksanaan penegakkan hukum, hak-hak asasi yang melekat pada diri tersangka tidak boleh dikurangi. 
Fungsi advokat baik secara perorangan maupun organisasi menurut Undang-undang Nomor 18 Tahun 2003 dihubungkan dengan kewajiban memberikan bantuan hukum terhadap tersangka dalam perkara penyalahgunaan Narkotika adalah belum efektif karena dalam ketentuan tersebut tidak ada sanksi yang tegas yang dapat dikenakan kepada Advokat jika seorang advokat atau organisasi advokat menolak untuk memberikan bantuan hukum kepada pencari keadilan bagi tersangka perkara penyalahgunaan Narkotika. Mengenai tanggung jawab Advokat terhadap kewajiban dalam jasa pelayanan hukum yaitu mengenai ketentuan tanggung jawab Advokat tentang pelayanan jasa hukum yang diatur dalam Undang-Undang Advokat dan kode Etik Profesi Advokat belum dapat mengantisipasi keutuhan praktik, karena tanggung jawab yang di atur oleh Undang-Undang Advokat dan Kode Etik Profesi Advokat hanya sebatas tanggung jawab dalam bentuk menjalankan kewajiban-kewajiban selaku Advokat dan meninggalkan larangan-larangan melakukan perbuatan tertentu bukan dalam bentuk tanggung jawab dalam memberikan pelayanan jasa hukum. Untuk itu prinsip tanggung jawab mutlak dapat diterapkan terhadap profesi Advokat.

\section{Saran}

Mengingat pentingnya bantuan hukum bagi tersangka dalam perkara penyalahgunaan Narkoba maka perlu kiranya dibuat segera Undang-undang tentang bantuan hukum atau peraturan pemerintah yang mengatur tentang tata cara pemberian bantuan hukum oleh advokat, agar ada jaminan kepada tersangka dan terdakwa dalam mendapatkan bantuan hukum dan prosedur yang jelas tentang tata cara pemberian bantuan hukum oleh advokat secara individu maupun organisatoris serta kepada pemerintah dituntut tanggungjawab yang besar dalam pelaksanaaan bantuan hukum yang antara lain dalam bentuk penyediaan sistem yang memastikan bantuan hukum dapat bekerja efektik, fasilitas maupun dukungan dana. Dimana harus mengalokasikan melalui anggaran Pendapatan Belanja Negara (APBN) untuk bantuan hukum.

Perlu kiranya diajukan rekomendasi agar merevisi Undang-undang Nomor 8 Tahun 1981 tentang KUHAP khususnya Pasal 56 dan 115 ayat (1) serta Pasal 114 
KUHAP yang mengatur tentang bantuan hukum dan peran advokat dimana ditegaskan bahwa bantuan adalah hak dan dapat dipergunakan dirubah atau ditambah beberapa Pasal menjadi bantuan hukum wajib diberikan kepada tersangka. Dan juga merevisi Undang-Undang No. 18 Tahun 2003 tentang Advokat agar efektif dengan adanya ketentuan sanksi yang tegas dikenakan kepada advokat, jika seseorang advokat atau organisasi advokat menolak untuk memberikan bantuan hukum kepada pencari keadilan dan tercantum juga mengenai prinsip tanggung jawab mutlak dalam memberikan pelayanan jasa hukum.

\section{DAFTAR PUSTAKA}

Amir, S. M. (1976). Hukum Acara Pengadilan Negeri. Pradnya Paramita.

Bambang Sunggono, A. H. (2001). Bantuan Hukum dan Hak Asasi Manusia. Mandar Maju.

BNN. (2004). Pedoman Pencegahan Penyalahgunaan Narkoba Bagi pemuda. BNN.

C. Samosir, D. (1985). Hukum Acara Pidana dalam Perbandingan. Binacipta.

Ebbe, O. N. I. (2013). Comparative and International Criminal Justice Systems. CRC Press.

Fletcher, G. P. (1998). Basic Concept of Criminal Law. Oxford University Press.

Kaligis, O. C. (2006). Perlindungan Hukum Atas Hak Asasi Tersangka, terdakwa dan terpidana. Alumni.

Loqman, L. (1990). Kekuasaan Kehakiman, Tinjauan Dari Segi Hukum Acara Pidana. CV. Data Com.

Manan, B. (1998). Demokrasi Pancasila.

Reksodiputro, M. (1997). Bunga Rampai Permasalahan Dalam Sistem Peradilan Pidana. Universitas Indonesia.

Reksodiputro, M. (1998). KUHAP dan Hak Asasi Manusia. Harian Republika.

Reksodiputro, M. (2003). Perlindungan HAM melalui Asas Praduga Tidak Bersalah dan Asas Persamaan Kedudukan Dalam Hukum Pada Sistem Peradilan Pidana Indonesia (1st ed.). Alumni.

Sahetapy, J. E. (1982). Studi Khusus Mengenai Ancaman Pidana Mati terhadap Pembunuhan Berencana. Rajawali.

Sapardjaja, K. E. (2002). Ajaran Sifat Melawan Hukum Materiil Dalam Hukum Pidana Indonesia. Alumni.

Wahid, A. (1994). Menggugat Idealisme KUHAP. Tarsito. 